\title{
Antileishmanial activity of some Brazilian plants, with particular reference to Casearia sylvestris
}

\author{
LUCIANA M.R. ANTINARELLI ${ }^{1}$, NÍCOLAS C. PINTO ${ }^{2}$, \\ ELITA SCIO ${ }^{2}$ and ELAINE S. COIMBRA ${ }^{1}$ \\ ${ }^{1}$ Departamento de Parasitologia, Microbiologia e Imunologia/ICB, \\ Universidade Federal de Juiz de Fora, Campus Universitário, \\ Bairro São Pedro, 36036-900 Juiz de Fora, MG, Brasil \\ ${ }^{2}$ Laboratório de Produtos Naturais Bioativos, Departamento de Bioquímica/ICB, \\ Universidade Federal de Juiz de Fora, Campus Universitário, \\ Bairro São Pedro, 36036-900 Juiz de Fora, MG, Brasil
}

Manuscript received on June 11, 2014; accepted for publication on September 6, 2014

\begin{abstract}
Leishmaniasis is a complex of diseases caused by Leishmania protozoa which treatment is restricted to a limited number of drugs that exhibit high toxicity, collateral effects and are often costly. There are a variety of tropical plants distributed in Brazil, and for many poor people the therapy for several diseases is based mainly on the use of traditional herbal remedies. In this work, the cytotoxic activity of 17 plant methanol extracts was evaluated on several Leishmania species and murine macrophages. Among them, the extract of Casearia sylvestris, Piptocarpha macropoda, Trembleya parviflora, Samanea tubulosa and Plectranthus neochilus showed a promissing leishmanicidal activity, exhibiting $\mathrm{IC}_{50}$ values below of $20 \mu \mathrm{g} / \mathrm{mL}$ against at least one species of Leishmania. Casearia sylvestris showed the most expressive activity against all promastigote forms of Leishmania species ( $\mathrm{IC}_{50}$ values of $5.4 \mu \mathrm{g} / \mathrm{mL}, 5.0 \mu \mathrm{g} / \mathrm{mL}, 8.5 \mu \mathrm{g} / \mathrm{mL}$ and $7.7 \mu \mathrm{g} /$ $\mathrm{mL}$ for L. amazonensis, L. braziliensis, L. chagasi and L. major, respectively), being more effective than the reference drug miltefosine. In spite of the cytotoxic effect on macrophages $\left(C_{50}\right.$ value of $\left.5.2 \mu \mathrm{g} / \mathrm{mL}\right), C$. sylvestris exhibited a strong inhibition against intracellular amastigotes of $L$. braziliensis $\left(\mathrm{IC}_{50}\right.$ value of $1.3 \mu \mathrm{g} /$ $\mathrm{mL}$ ). Further studies, including bio-guided fractionation will be conducted to identify the active compounds.
\end{abstract}

Key words: Brazil, Casearia sylvestris, leishmanicidal activity, medicinal plants, natural products.

\section{INTRODUCTION}

Leishmaniasis is a vector borne disease caused by protozoa parasites of the genus Leishmania (WHO 2010). According to the World Health Organization, leishmaniasis is considered a major Neglected Tropical Disease with expressive economic, social,

Correspondence to: Elaine Soares Coimbra

E-mail: elaine.coimbra@ufjf.edu.br and political impacts. Leishmaniasis is distributed in more than 90 countries, with an annual incidence of 1.5 to 2.0 million cases, and 350 million people under the risk of infection (WHO 2013).

Leishmaniasis comprises a complex of clinical manifestations including ulcerative skin lesions, destructive mucosal inflammation, and disseminated visceral infection in its most severe form (Murray 
et al. 2005). These clinical manifestations occur due to a complex interaction between the parasite and the immune response of the mammalian host.

Current chemotherapeutic agents for the treatment of all clinical manifestations of leishmaniasis are pentavalent antimonials compounds (e.g., sodium stibogluconate and meglumine antimoniate) and amphotericin B, which unfortunately are considerably toxic (Croft and Olliaro 2011, Tempone et al. 2011, Singh and Sundar 2012). Furthermore, these drugs exhibit several limitations, including high cost and the need for daily parenteral administration (Singh and Sundar 2012). More recently the antitumor drug miltefosine was introduced as the first and still the only oral therapeutic option for the treatment of visceral leishmaniasis in India (Sundar et al. 2002, Dorlo et al. 2012).

There are a variety of tropical plants distributed in Brazil and for many poor people the therapy for several diseases is based mainly on the use of traditional herbal remedies (Lorenzi and Matos 2002). In most cases, these plants are used without any scientific base. In the last years, several works showed the leishmanicidal effect of some Brazilian plant extracts or essential oils (Santin et al. 2009, Albernaz et al. 2010, Alviano et al. 2012, Brito et al. 2013). In a previous work, we reported the antileishmanial activity of extracts of 20 plants from the Brazilian flora (Braga et al. 2007). Due to our continuous search for new alternatives for the treatment of leishmaniasis, this study aimed to investigated the leishmanicidal activity of 17 plant methanolic extracts against four Leishmania species and murine macrophages.

\section{MATERIALS AND METHODS}

\section{PlANT MATERIAL}

Specimens of 17 species were collected in Juiz de Fora, Minas Gerais, Brazil. A voucher specimen was deposited at the Herbarium Leopoldo Krieger (CESJ) of the Federal University of Juiz de Fora.
Table I shows the botanical name, local name, voucher specimen number and the popular uses of the plants tested.

Preparation of Plant Extracts

The dried parts of the plants (50 g each) were powdered and macerated with methanol (3x $200 \mathrm{ml}$ ) for five days at room temperature. After evaporation of the solvent under reduced pressure, the respective methanolic extracts were obtained. All extracts were kept dried in tightly stoppered bottles under refrigeration $\left(4{ }^{\circ} \mathrm{C}\right)$ until used for the biological tests.

ANTILEISHMANIAL ACTIVITY

\section{Parasites}

Four Leishmania species were used for in vitro screening: L. amazonensis (IFLA/Br/67/PH8), L. major (MRHO/SU/59/P), L. braziliensis (MHOM/ $\mathrm{Br} / 75 / \mathrm{M} 2903$ ) and L chagasi (MHOM/Br/74/PP75). Promastigotes of L. amazonensis were cultured in Warren's medium [brain heart infusion- BHI (Himedia, Mumbai, Indian), plus hemin and folic acid (Sigma Chemical Co, St. Louis, MO, USA)], promastigotes of $L$. major and $L$. braziliensis were maintained in Medium BHI, and promastigotes of $L$. chagasi were maintained in Medium 199 (Cultilab, Campinas, São Paulo, Brazil), both supplemented with 10\% fetal bovine serum (FBS; Cultilab, Campinas, São Paulo, Brazil) at $25^{\circ} \mathrm{C}$.

Antipromastigote assay: The antileishmanial activity was determined by the colorimetric 3-(4,5-dimethylthiazol-2-yl)-2,5-diphenyltetrazolium bromide (MTT; Sigma-Aldrich, St. Louis, MO, USA) method based on tetrazolium salt reduction by mitochondrial dehydrogenases (Mossman 1983). Briefly, promastigotes from a logarithmic phase culture were suspended to yield 2 millions of cells $/ \mathrm{mL}$ ( $L$. amazonensis) or 3 millions of cells $/ \mathrm{mL}$ (L. chagasi, L. braziliensis and $L$. major) after Neubauer chamber counting. 
The screening was performed in 96-well microtiter plates maintained at $25^{\circ} \mathrm{C}$. The analyses were made in duplicate. The extracts were dissolved in dimethyl sulfoxide (DMSO; Sigma-Aldrich, St. Louis, MO, USA) as a stock solution. Parasites were exposed to increasing concentration of the extracts solutions (at minimum five serial dilutions) for $72 \mathrm{~h}$ at $25{ }^{\circ} \mathrm{C}$. Controls containing $0.5 \% \mathrm{DMSO}$ and medium alone were also included. The viability of promastigotes was obtained by measuring the absorbance at 570 nm (Multiskan MS microplate reader, LabSystems Oy, Helsink, Finland). Amphotericin B (Cristalia, São Paulo, Brazil) and miltefosine (Cayman Chemical Company, Michigan, USA) were used as reference drugs.

Antiamastigote assay: Inflammatory macrophages were obtained from the peritoneal cavity of $\mathrm{BALB} / \mathrm{c}$ mice previously inoculated with $3 \%$ thioglycollate medium (Sigma Chemical Co; St. Louis, MO, USA). After $72 \mathrm{~h}$, the peritoneal exudate was collected by washing with cold Hank's Balanced Sal Solution (Sigma Chemical Co; St. Louis, MO, USA) (Silva et al. 2012). Briefly, peritoneal macrophages added at $2 \times 10^{6}$ cells $/ \mathrm{mL}$ to coverslips (13 mm diameter) previously arranged in a 24-well plate in RPMI 1640 medium (Cultilab, Campinas, São Paulo, Brazil) supplemented with $10 \%$ inactivated FBS, and allowed to adhere at $37^{\circ} \mathrm{C}$ in $5 \% \mathrm{CO}_{2}$. Adherent macrophages were infected with L. braziliensis (MRHO/BR/75/M2903) or $L$. amazonensis (IFLA/Br/67/PH8) promastigotes in the stationary growth phase using a 1:10 ratio at $33{ }^{\circ} \mathrm{C}$ for $4 \mathrm{~h}$. After this time, the no phagocytosed promastigotes were removed washing twice in sterile Phosphate Buffered Saline (PBS) and the test samples were added at nontoxic concentrations to the macrophages $(5.0,1.0$ and $0.1 \mu \mathrm{g} / \mathrm{mL})$ and maintained at $33{ }^{\circ} \mathrm{C} 5 \% \mathrm{CO}_{2}$ for $72 \mathrm{~h}$. Cells were washed, fixed with absolute ethanol, and stained with Giemsa. Cells were then dehydrated in acetone followed by a gradient acetone-xylol $(9: 1 ; 1: 1 ; 1: 9)$ and finally xylol. The slides were mounted with
Canada balsam for parasite counting at a optical microscopy (1000x magnification). At least 100 infected cells were counted and the results were expressed as Index infection, obtained multiplying the percentage of infected cells by mean number of amastigotes per cell. Miltefosine was used as reference drug. All procedures were performed in agreement with the Ethical Principles in Animal Research and according to protocols approved by the "Pró-Reitoria de Pesquisa/UFJF - Ethical Committee for Animal Research" (\#016/2012-CEEA).

\section{CyTOTOXICITY ON MAMMALIAN CELLS}

Murine macrophages were obtained and cultured as described before. Briefly, the inflammatory peritoneal macrophages were used for cytotoxicity assay in a concentration of $2 \times 10^{6}$ cells $/ \mathrm{mL}$ in $96-$ well culture plates in RPMI 1640 medium supplemented with $10 \%$ inactivated FBS, at $37{ }^{\circ} \mathrm{C}$ and $5 \% \mathrm{CO}_{2}$ atmosphere. After $24 \mathrm{~h}$, the adherent macrophages were incubated with the extracts in a serial dilution, in duplicate at each concentration for $72 \mathrm{~h}$ at $37^{\circ} \mathrm{C}$ and $5 \% \mathrm{CO}_{2}$ atmosphere. The viability of the macrophages was determined with the MTT assay using a multiwall scanning spectrophotometer (Multiskan EX microplate reader), as described above, and was confirmed by comparing the morphology with the control (macrophages incubated in RPMI 1640 medium supplemented with $10 \%$ inactivated FBS), via light microscopy. Dose response curves were plotted (values expressed as percentage of control optical density) and the values were expressed as $\mathrm{CC}_{50}$ values $(50 \%$ cytotoxicity concentration). All procedures were performed in agreement with the Ethical Principles in Animal Research and according to protocols approved by the "Pró-Reitoria de Pesquisa/UFJF - Ethical Committee for Animal Research" (\#015/2012-CEEA).

\section{STATISTICAL ANALYSIS}

For Leishmania and murine macrophages assays, the $\mathrm{IC}_{50}$ or $\mathrm{CC}_{50}$ values, respectively, were carried out and the $95 \%$ confidence intervals were included, 
calculated by Litchtfiet and Wilcoxon method using the Probit analysis, and the graphs were plotted by the program GraphPad Prism 4 (GraphPad Software, San Diego, CA, USA). One-way ANOVA followed by Dunnett post test were used. Differences were regarded as significant when $p<0.0001(* * *)$ and $p<0.001(* *)$.

\section{RESULTS AND DISCUSSION}

In the present work, 17 methanolic plant extracts were evaluated for antileishmanial activity against promastigote forms of Leishmania and citotoxicity against murine macrophages. In addition the efficacy of the most promising plant extract against intracellular amastigotes of Leishmania sp was also evaluated. Table I shows the botanical name, local name, voucher specimen number and popular uses of the tested plants.

Table II shows the extracts effect on promastigote forms of different Leishmania species: three from the New World (L. braziliensis, L. chagasi and $L$. amazonensis) and one species from the Old World (L. major) (Santos et al. 2008). Due to this, a different sensitivity of theses parasites to the tested extracts was expected. Previous in vitro studies have also shown differences in sensitivity of Leishmania species to different reference drugs, including pentavalent antimonials, amphotericin B (Minodier and Parola 2007), miltefosine (De Morais-Teixeira et al. 2011) and crude or purified plant extracts (Braga et al. 2007, Fabri et al. 2012a, b). Among the 17 methanolic extracts tested, 11 showed leishmanicidal activity against at least one promastigote forms of Leishmania species with $\mathrm{IC}_{50}$ values ranging from 5.0 to $88.3 \mu \mathrm{g} / \mathrm{mL}$. Interestingly, in a general biological evaluation, the tested extracts were more active against $L$. braziliensis, responsible for cutaneous and mucocutaneous leishmaniasis; and against $L$. chagasi promastigote forms, the causative agent of fatal visceral leishmaniasis in the American continent (Cruz et al. 2009). Promastigotes of L. amazonensis were less sensitive to the extracts assayed.
Phytochemical screening of most of the extracts assayed in this study was previously reported and a variety of secondary metabolites was related to these extracts such as alkaloids, triterpens, sterols, tannins, saponins and flavonoids (Scio et al. 2012). In this work, among the extracts assayed, Casearia sylvestris, Piptocarpha macropoda, Trembleya parviflora, Samanea tubulosa and Plectranthus neochilus showed strong leishmanicidal activity, exhibiting $\mathrm{IC}_{50}$ values below of $20 \mu \mathrm{g} / \mathrm{mL}$, for at least one species of Leishmania. Biological activity of $C$. sylvestris, $P$. macropoda and $S$. tubulosa could be due to the presence of secondary metabolites such as alkaloids, sterols, tannins and flavonoids (Scio et al. 2012). C. sylvestris showed remarkable activity against promastigotes of all Leishmania species, with $\mathrm{IC}_{50}$ below $10 \mu \mathrm{g} /$ $\mathrm{mL}$, being more effective than the reference drug miltefosine (Table II), which is currently the only oral drug available for the treatment of visceral leishmaniasis (De Morais-Teixeira et al. 2011). So, this plant extract was selected for further analysis against intracellular amastigote forms, since this form of parasite is found in the mammalian host and is important for human disease. Amastigotes of $L$. braziliensis and L. amazonensis were used as model in order to determine the antileishmanial property of C. sylvestris against intracellular forms of parasite (Fig. 1 and Table III). The effectiveness of $C$. sylvestris extract on the infection rate of the infected macrophages and the intracellular replication of the amastigote forms was determined by the infection index. Figure 1 shows the dose-dependent effect of this extract on amastigotes of L. amazonensis and L. braziliensis. Amastigotes of L. braziliensis were most sensitive to the treatment with $C$. sylvestris extract and the inhibition of infection index was $62.1 \% ; 64.0 \%$ and $65.0 \%(0.5 \mu \mathrm{g} / \mathrm{mL} ; 1.0 \mu \mathrm{g} / \mathrm{mL}$ and $5.0 \mu \mathrm{g} / \mathrm{mL}$, respectively). Furthermore, $\mathrm{IC}_{50}$ value for this extract against $L$. braziliensis amastigotes was very low $(1.3 \mu \mathrm{g} / \mathrm{mL})$, and highlighted the activity of extract against intracellular form of the 
TABLE I

Ethnomedical data on medicinal plants.

\begin{tabular}{|c|c|c|c|c|c|}
\hline Family & $\begin{array}{c}\text { Botanical name } \\
\text { [Voucher number] }\end{array}$ & Common name & $\begin{array}{l}\text { Parts } \\
\text { used }^{\mathrm{a}}\end{array}$ & Ethnomedical uses & References \\
\hline \multirow{5}{*}{ Asteraceae } & $\begin{array}{l}\text { Achillea millefolium L. } \\
\text { [CESJ 46087] }\end{array}$ & $\begin{array}{l}\text { Novalgina, erva-de- } \\
\text { carpinteiro, aquiléia, } \\
\text { milefólio }\end{array}$ & $\mathrm{L}$ & $\begin{array}{l}\text { Fever, headaches and general } \\
\text { aches,colds, indigestion }\end{array}$ & $\begin{array}{l}\text { Lorenzi and } \\
\text { Matos } 2002\end{array}$ \\
\hline & $\begin{array}{l}\text { Anthemis cotula } \mathrm{L} \text {. } \\
\text { [CESJ 48584] }\end{array}$ & Camomila-do-campo & $\mathrm{L}$ & $\begin{array}{l}\text { Fever, gastrointestinal disorders, } \\
\text { dysenteria, gouty arthritis }\end{array}$ & $\begin{array}{l}\text { Corrêa and } \\
\text { Penna } 1984\end{array}$ \\
\hline & $\begin{array}{l}\text { Bidens segetum Mart. } \\
\text { ex Colla [CESJ 47437] }\end{array}$ & Picão-do-mato & $\mathrm{L}$ & No use reported & \\
\hline & $\begin{array}{c}\text { Piptocarpha } \\
\text { macropoda (DC.) } \\
\text { Baker [CESJ 49448] }\end{array}$ & & $\mathrm{L}$ & No use reported & \\
\hline & $\begin{array}{l}\text { Vernonanthura } \\
\text { divaricata (Spreng.) H. } \\
\text { Rob. [CESJ 49450] }\end{array}$ & Cambará-açu & $\mathrm{L}$ & No use reported & \\
\hline Euphorbiaceae & $\begin{array}{l}\text { Alchornea triplinervia } \\
\text { (Spreng.) Müll. Arg. } \\
\text { [CESJ 49442] }\end{array}$ & $\begin{array}{l}\text { Tapiá-vermelho, tapiágua- } \\
\text { çu-branco, pau-óleo }\end{array}$ & $\mathrm{L}$ & Gastric disturbances & $\begin{array}{l}\text { Lima et al. } \\
\quad 2011\end{array}$ \\
\hline \multirow[b]{2}{*}{ Fabaceae } & $\begin{array}{c}\text { Chamaecrista } \\
\text { desvauxii (Collad.) } \\
\text { Killip [CESJ 23372] }\end{array}$ & $\begin{array}{c}\text { Sene, acácia, carquejado- } \\
\text { tabuleiro, flor-de-lilás, } \\
\text { capim reis }\end{array}$ & $\mathrm{L}$ & $\begin{array}{l}\text { Wounds in the uterus, worms, } \\
\text { bowel, arthritis }\end{array}$ & $\begin{array}{c}\text { Moreira and } \\
\text { Guarim-Neto } \\
2009\end{array}$ \\
\hline & $\begin{array}{c}\text { Samanea tubulosa } \\
\text { (Benth.) Barneby \& } \\
\text { J.W. Grimes } \\
\text { [CESJ 49743] }\end{array}$ & $\begin{array}{l}\text { Amendoim-de-veado, } \\
\text { árvore-da-chuva e pau- } \\
\text { de-cangalha }\end{array}$ & $\mathrm{L}$ & Eye disorders & $\begin{array}{l}\text { Hajdu and } \\
\text { Hohmann } \\
2012\end{array}$ \\
\hline Flacourtiaceae & $\begin{array}{c}\text { Casearia sylvestris } S w . \\
\text { [CESJ 49218] }\end{array}$ & $\begin{array}{l}\text { Guaçatonga, bugre- } \\
\text { branco, café-bravo, café- } \\
\text { de-frade }\end{array}$ & $\mathrm{L}$ & $\begin{array}{c}\text { Burns, cutaneous injuries, herpes, } \\
\text { tonic, depurative, rheumatism, } \\
\text { inflammation, analgesic, } \\
\text { hemostatic, gastritis }\end{array}$ & $\begin{array}{c}\text { Moreira and } \\
\text { Guarim-Neto } \\
2009\end{array}$ \\
\hline \multirow{3}{*}{ Lamiaceae } & $\begin{array}{l}\text { Leonurus sibiricus L. } \\
\text { [CESJ 46176] }\end{array}$ & Macaé & $\mathrm{L}$ & $\begin{array}{c}\text { Intestinal problems, cough, } \\
\text { bronchitis, gastric defect, } \\
\text { rheumatism, fever diseases of eyes }\end{array}$ & $\begin{array}{l}\text { Lorenzi and } \\
\text { Matos } 2002\end{array}$ \\
\hline & $\begin{array}{l}\text { Ocimum basilicum } \mathrm{L} . \\
\text { [CESJ 46161] }\end{array}$ & Manjericão, alfavaca & $\mathrm{L}$ & $\begin{array}{c}\text { Gastrointestinal disorders, fever, } \\
\text { digestive, bacterial infections, } \\
\text { parasitosis }\end{array}$ & $\begin{array}{l}\text { Lorenzi and } \\
\text { Matos } 2002\end{array}$ \\
\hline & $\begin{array}{l}\text { Plectranthus neochilus } \\
\text { Schltr. [CESJ 46580] }\end{array}$ & Boldo & $\mathrm{L}$ & $\begin{array}{l}\text { Treatment of respiratory } \\
\text { infections or related symptoms, } \\
\text { gastrointestinal disorders, skin } \\
\text { infections, hepatic insufficiency }\end{array}$ & $\begin{array}{c}\text { Caixeta et al. } \\
2011\end{array}$ \\
\hline Melastomataceae & $\begin{array}{l}\text { Trembleya parviflora } \\
\text { (D. Don) Cogn. } \\
\text { [CESJ 49219] }\end{array}$ & Manacá & $\mathrm{L}$ & No use reported & \\
\hline Myrtaceae & $\begin{array}{l}\text { Syzygium malaccense } \\
\text { (L.) Merr. and } \\
\text { L.M.Perry [CESJ } \\
46600]\end{array}$ & Jambo & $\mathrm{L}$ & Inflammation & $\begin{array}{c}\text { Dustan et al. } \\
1997\end{array}$ \\
\hline Poaceae & $\begin{array}{c}\text { Cymbopogon citratus } \\
\text { (DC) Stapf. } \\
\text { [CESJ 46582] }\end{array}$ & $\begin{array}{l}\text { Capim-cheiroso, erva- } \\
\text { cidreira, Capim-cidreira, } \\
\text { capim-limão }\end{array}$ & AP & $\begin{array}{l}\text { Calmative, gastrointestinal } \\
\text { disorders, infectious diseases, } \\
\text { colic treatment, anxiety }\end{array}$ & $\begin{array}{c}\text { Albuquerque } \\
1989\end{array}$ \\
\hline Tropaeolaceae & $\begin{array}{l}\text { Tropaeolum majus L. } \\
\text { [CESJ 46586] }\end{array}$ & $\begin{array}{l}\text { Capuchinha, chaguinha, } \\
\text { alcaparra-de- pobre, } \\
\text { chagas, mastruço-do-peru }\end{array}$ & $\mathrm{L}$ & $\begin{array}{l}\text { Scurvy, sepses, expectorant, } \\
\text { urinary, gastrointestinal and } \\
\text { dermatological disinfectant }\end{array}$ & $\begin{array}{l}\text { Lorenzi and } \\
\text { Matos } 2002\end{array}$ \\
\hline Verbenaceae & $\begin{array}{l}\text { Lippia rubella } \\
\text { (Moldenke) T.R.S. } \\
\text { Silva \& Salimena } \\
\text { [CESJ 46178] }\end{array}$ & & $\mathrm{AP}$ & No use reported & \\
\hline
\end{tabular}

\footnotetext{
${ }^{\mathrm{a}} \mathrm{AP}$, aerial parts; L, leaves.
} 
TABLE II

Effect of plant extracts in promastigotes of

Leishmania species and murine macrophages.

\begin{tabular}{|c|c|c|c|c|c|c|}
\hline \multirow[t]{2}{*}{ Plants } & \multirow{2}{*}{$\begin{array}{c}\text { Parts } \\
\text { of } \\
\text { plants }\end{array}$} & \multicolumn{4}{|c|}{$\begin{array}{l}\text { Antileishmanial activity } \\
\mathrm{IC}_{50}(\mu \mathrm{g} / \mathrm{mL})(95 \% \text { C.I. })\end{array}$} & \multirow{2}{*}{$\begin{array}{l}\text { Macrophages } \\
\mathrm{CC}_{50}(\mu \mathrm{g} / \mathrm{mL})\end{array}$} \\
\hline & & $L . a^{l}$ & $L . m^{2}$ & $L . b^{3}$ & L.c ${ }^{4}$ & \\
\hline Casearia cf. sylvestris & Leaves & $5.4(4.3-6.8)$ & $7.7(6.7-8.8)$ & $5.0(4.5-5.7)$ & $8.5(5.8-12.4)$ & $5.2(4.0-6.4)$ \\
\hline $\begin{array}{l}\text { Piptocarpha cf. } \\
\text { macropoda }\end{array}$ & Leaves & $10.3(9.0-11.7)$ & $9.2(7.5-11.2)$ & $7.4(5.7-9.5)$ & $26.3(21.8-31.6)$ & $4.1(3.6-4.8)$ \\
\hline Leonorus sibiricus & Leaves & $53.2(47.4-59.7)$ & $53.6(45.5-63.1)$ & $46.9(42.4-51.9)$ & $>108.0$ & $>111.0$ \\
\hline Cymbopogon citratus & $\begin{array}{l}\text { Aerial } \\
\text { Parts }\end{array}$ & $33.4(29.4-37.9)$ & $20.6(17.8-23.6)$ & $51.1(46.2-56.3)$ & $34.6(23.2-51.8)$ & $>111.0$ \\
\hline Trembleya parviflora & Leaves & $19.7(17.0-22.7)$ & $>108.0$ & $17.1(14.0-20.9)$ & $64.0(54.6-75.2)$ & $83.8(67.0-104.8)$ \\
\hline $\begin{array}{l}\text { Vernonanthura } \\
\text { divaricata }\end{array}$ & Leaves & $37.1(31.7-43.4)$ & $>108.0$ & $28.0(24.4-32.3)$ & $61.8(49.2-77.7)$ & $>111.0$ \\
\hline Alchornea triplinervia & Leaves & $>108.0$ & $36.3(31.6-41.7)$ & $67.1(59.7-75.4)$ & $>108.0$ & $102.5(80.5-130.6)$ \\
\hline Samanea tubulosa & Leaves & $>108.0$ & $>108.0$ & $>108.0$ & $19.0(16.0-22.6)$ & $86.6(70.4-106.5)$ \\
\hline Tropaeolum majus & Leaves & $>108.0$ & $61.5(50.5-74.9)$ & $>108.0$ & $>108.0$ & $>111.0$ \\
\hline Plectranthus neochilus & Leaves & $>108.0$ & $>108.0$ & $>108.0$ & $14.0(9.5-20.7)$ & $>111.0$ \\
\hline Achillea millefolium & Leaves & $>108.0$ & $30.8(26.8-35.5)$ & $>108.0$ & $>108.0$ & $>111.0$ \\
\hline Lippia rubella & $\begin{array}{l}\text { Aerial } \\
\text { Parts }\end{array}$ & $>108.0$ & $>108.0$ & $>108.0$ & $\begin{array}{l}88.3(70.8- \\
110.9)\end{array}$ & $>111.0$ \\
\hline Ocimum basilicum & Leaves & $>108.0$ & $>108.0$ & $>108.0$ & $>108.0$ & $>111.0$ \\
\hline Syzygium malaccense & Leaves & $>108.0$ & $>108.0$ & $>108.0$ & $>108.0$ & $>111.0$ \\
\hline Bidens segetum & Leaves & $>108.0$ & $>108.0$ & $>108.0$ & $>108.0$ & $>111.0$ \\
\hline Anthemis cotula & Leaves & $>108.0$ & $>108.0$ & $>108.0$ & $>108.0$ & $>111.0$ \\
\hline $\begin{array}{l}\text { Chamaecrista } \\
\text { desvauxii }\end{array}$ & Leaves & $>108.0$ & $>108.0$ & $>108.0$ & $>108.0$ & $>111.0$ \\
\hline $\mathrm{AmB}$ & & $0.11(0.09-0.12)$ & $0.10(0.09-0.11)$ & $0.12(0.09-0.14)$ & $0.05(0.05-0.06)$ & $122.7(98.4-153.1)$ \\
\hline Miltefosine & & $11.8(10.0-14.0)$ & $8.8(7.6-10.1)$ & $10.4(9.0-12.1)$ & $8.3(7.2-9.5)$ & $49.4(43.8-55.7)$ \\
\hline
\end{tabular}

${ }^{\mathrm{a}}$ Data are $\mathrm{IC}_{50}$ values in $\mu \mathrm{g} / \mathrm{mL}$ and $95 \%$ confidence intervals are in brackets. ${ }^{1}$ L.a. $=$ Leishmania amazonensis; ${ }^{2}$ L.m. $=$ L. major; ${ }^{3} \mathrm{~L}$. b. $=$ L. braziliensis and ${ }^{4}$ L.c. $=$ L. chagasi. These data represent the average of three independent experiments. AmB (amphotericin B) and miltefosine were used as reference drug. The highest concentration used of DMSO was $0.1 \%(\mathrm{v} / \mathrm{v})$, which is not toxic to the parasites.

TABLE III

Effect of Casearia cf. sylvestris extract on Leishmania braziliensis, specificity and selectivity index.

\begin{tabular}{|c|c|c|c|c|c|c|}
\hline & $\begin{array}{l}\text { Promastigotes } \\
\text { IC }_{50}(\mu \mathrm{g} / \mathrm{mL})\end{array}$ & $\begin{array}{c}\text { Amastigotes }^{\mathrm{IC}} \mathrm{C}_{50} \\
(\mu \mathrm{g} / \mathrm{mL})\end{array}$ & $\begin{array}{l}\text { Macrophages } \\
\mathrm{CC}_{50}(\mu \mathrm{g} / \mathrm{mL})\end{array}$ & ${ }^{\mathrm{a}} \mathbf{S I} \mathbf{I}_{\mathrm{PRO}}$ & ${ }^{\mathrm{b}} \mathbf{S I} \mathbf{I}_{\mathrm{AMA}}$ & ${ }^{\mathrm{c}} \mathrm{SP} \mathrm{PRO/AMA}$ \\
\hline Casearia sylvestris & 5.0 & 1.3 & 5.2 & 1.0 & 4.0 & 3.8 \\
\hline Miltefosine & 10.4 & 2.4 & 49.4 & 4.7 & 20.6 & 4.3 \\
\hline
\end{tabular}

$\mathrm{IC}_{50}$ (Inhibitory concentration at $50 \%$ inhibition). $\mathrm{CC}_{50}$ (Cytotoxic concentration at $50 \%$ inhibition). ${ }^{\text {a }} \mathrm{SI}$ : selectivity index $\left(\mathrm{CC}_{50}\right.$ of macrophages $/ \mathrm{IC}_{50}$ of promastigotes). ${ }^{\mathrm{b}} \mathrm{SI}$ : selectivity index $\left(\mathrm{CC}_{50}\right.$ of macrophages $/ \mathrm{IC}_{50}$ of amastigotes). ${ }^{\mathrm{c}} \mathrm{SP}$ : specificity index (ratio between promastigotes $\mathrm{IC}_{50}$ and intracellular amastigotes $\mathrm{IC}_{50}$ ). Miltefosine was used as reference drug.

parasite (Table III). In addition, Table III furnishes information about the selectivity and specificity of C. sylvestris extract. Regarding selectivity, when this value is greater than 1 , the extract is more selective against the parasite than macrophages, otherwise the extract is more toxic for macrophages (Tempone et al. 2010). As can be observed, besides the toxic effect on macrophages, when the extract 


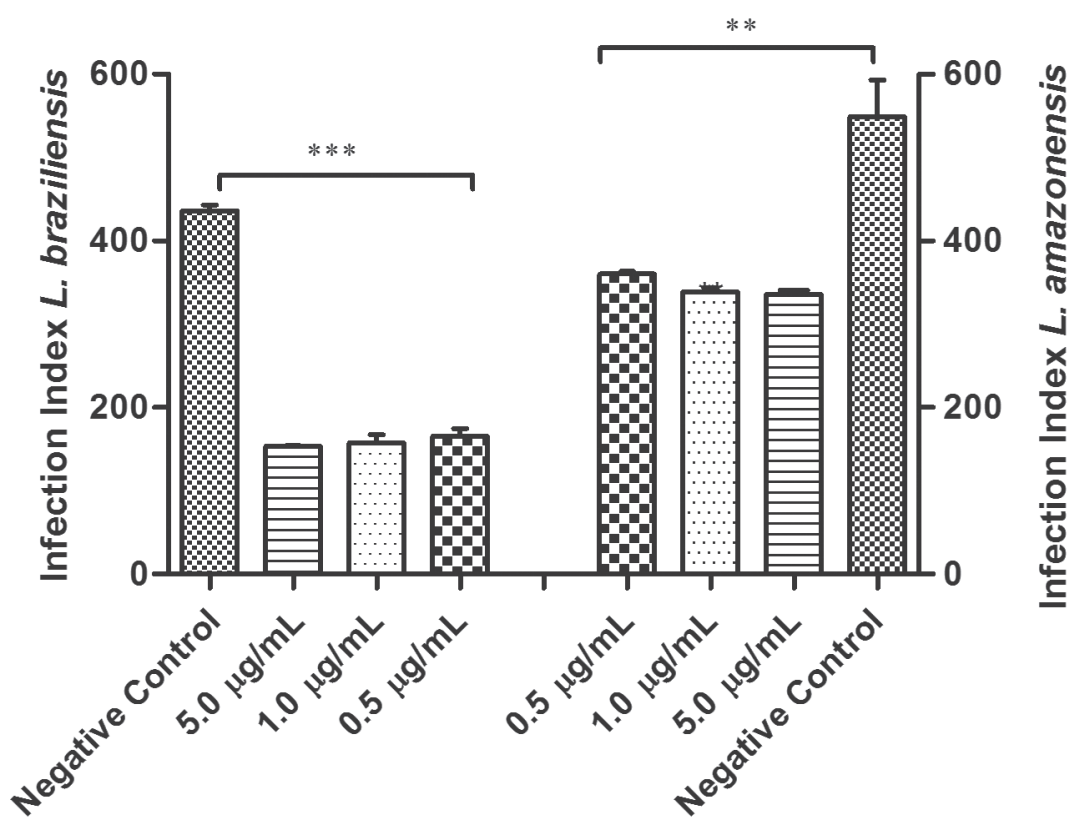

Figure 1 - Effect of Casearia sylvestris extract on L. braziliensis and L. amazonensis infected macrophages. Peritoneal macrophages previously infected with $L$. braziliensis or L. amazonensis promastigotes in the stationary growth phase were exposed to the compounds for $72 \mathrm{~h}$ and the results were expressed as the infection index (percentage of infected macrophages $\mathrm{x}$ mean number of parasites per cells). The test considered the mean of two assays performed in duplicate. Differences were regarded as significant when $p<0.0001(* * *)$ and $p<0.001(* *)$.

was assayed against amastigotes, it was much more destructive to parasite than to the host cells, being four-fold more selective against the parasite. De Muylder et al. (2011) established a cut-off regarding the specificity of compounds between these two stages of the parasite Leishmania sp. Specificity value $>2$ was the cut-off point chosen to define a compound as being more active against the intracellular amastigote stage; while a specificity value $<0.4$ indicated a more active compound against promastigotes; compounds with specificity values between 0.4 and 2 were considered as being active against both stages. It is interesting to point out that the extract was more specific for intracellular form of L. braziliensis (specificity index $=3.8$ ) and this result reinforces the potential leishmanicidal activity of $C$. sylvestris.

Previously, Mesquita et al. (2005) demonstrated the antileishmanial potential of $C$. sylvestris against promastigotes forms of $L$. donovani, of which extracts displayed a significant activity with $\mathrm{IC}_{50}$ values ranging from 0.1 to $4.9 \mu \mathrm{g} / \mathrm{mL}$ depending on the plant parts used.

Regarding the cytotoxicity effects on macrophages, $C$. sylvestris and P. macropoda were the most cytotoxic to mammalian cells (Table II). Cytotoxicity tests with natural products are important because they represent a potential source for the isolation of compounds for the development of new antiprotozoal agents (Brenzan et al. 2007).

Casearia sylvestris, which is popularly named "erva-de-lagarto", "língua-de-tiú", cafezinho-domato", "corta-lengua", is distributed throughout Brazil (Ferreira el al. 2011). Pharmacological studies have highlighted the promising bioactive potential of extracts and compounds isolated from C. sylvestris, especially its antitumor (Ferreira et al. 2010), anti-ulcer (Da Silva et al. 2008), antifungal (Alves et al. 2000), antibacterial (Chiappeta et al. 1983), antioxidant (Menezes et al. 2004) and 
molluscicide (Alves et al. 2000) activities. Regarding antiprotozoal properties of C. sylvestris, some authors have reported activity against Trypanosoma cruzi (Mesquita et al. 2005). Phytochemical studies have attributed the high antitumor activity of $C$. sylvestris to the numerous secondary metabolites, especially diterpenes, which are likely based on its larger hydrophobicity and facility to penetrate across cell membrane and interact with intracellular targets (Ferreira et al. 2010). Secundary metabolites of C. sylvestris, such as alkaloids, sterols, saponins, tannins and flavonoids may be associated with significant activity against Leishmania sp. However more investigations are necessary to determine the activity of each extract component separately and in combination to ensure whether they act alone or synergistically.

\section{CONCLUSION}

In conclusion, the methanolic extracts of Casearia sylvestris and Piptocarpha macropoda showed significant leishmanicidal activity, specially $C$. sylvestris extract, which may be a potential source of active compounds for the development of novel therapeutic agents to treat leishmaniasis.

\section{ACKNOWLEDGMENTS}

The authors are grateful to Fundação de Amparo à Pesquisa do Estado de Minas Gerais (FAPEMIG), Conselho Nacional de Desenvolvimento Científico e Tecnológico ( $\mathrm{CNPq}$ ) and UFJF for financial support, and to Dr. Fatima Regina Salimena and Dr.Tatiana Konno for the botanical identification of the species.

\section{RESUMO}

As leishmanioses são um complexo de doenças causadas por protozoários Leishmania, cujo tratamento é restrito a um número limitado de fármacos que apresentam toxicidade elevada, efeitos colaterais e geralmente custos elevados. Existe uma enorme variedade de plantas tropicais distribuídas no Brasil e para muitas pessoas pobres a terapia para várias doenças baseia-se principalmente no uso de remédios tradicionais obtidos de plantas. Neste trabalho, a atividade citotóxica de 17 extratos metanólicos de plantas foi avaliada em várias espécies de Leishmania e em macrófagos murinos. Dentre eles, os extratos de Casearia sylvestris, Piptocarpha macropoda, Trembleya parviflora, Samanea Tubulosa e Plectranthus neochilus mostraram atividade leishmanicida promissora, exibindo valores de $\mathrm{CI}_{50}$ abaixo de $20 \mu \mathrm{g} / \mathrm{mL}$ em pelo menos uma das espécies de Leishmania. Casearia sylvestris apresentou a atividade mais expressiva em todas as formas promastigotas de espécies de Leishmania (valores de $\mathrm{CI}_{50}$ de $5,4 \mu \mathrm{g} / \mathrm{mL}, 5,0 \mu \mathrm{g} / \mathrm{mL}, 8,5 \mu \mathrm{g} / \mathrm{mL}$ and $7,7 \mu \mathrm{g} / \mathrm{mL}$ em L. amazonensis, L. braziliensis, L. chagasi e L. major, respectivamente), sendo mais eficaz que o fármaco de referência miltefosina. Apesar do efeito citotóxico em macrófagos (valor de $\mathrm{CC}_{50}$ de $5,2 \mu \mathrm{g} / \mathrm{mL})$, C. sylvestris exibiu uma forte inibição em formas amastigotas de L. braziliensis (valor de $\mathrm{CI}_{50}$ de $1,3 \mu \mathrm{g} / \mathrm{mL}$ ). Mais estudos, incluindo fracionamento bio-guiado, serão realizados para identificar os compostos ativos.

Palavras-chave: Brasil, Casearia sylvestris, atividade leishmanicida, plantas medicinais, produtos naturais.

\section{REFERENCES}

Albernaz LC, PaUla JE, Romero ARS, Silva MRR, GREllier P, MAMBU L AND EsPINDOLA LS. 2010. Investigation of plant extracts in traditional medicine of the Brazilian Cerrado against protozoans and yeasts. J Ethnopharmacol 131: 116-121.

AlBUQUERQUE JM. 1989. Plantas medicinais de uso popular, Ministério da Educação. Brasília: ABEAS, 93 p.

Alves TMA, SILVA AF, BRANDÃo M, GRANDI TSM, SMÃNIA EFA, SMÃNIA JUNIOR A AND ZANI CL. 2000. Biological screening of Brazilian medicinal plants. Mem Inst Oswaldo Cruz 95: 363-373.

ALVIANO DS, BARRETO ALS, DIAS FA, RODRIGUES IA, ROSA MSS, ALVIANO CS AND SOARES RMA. 2012. Conventional therapy and promising plant-derived compounds against trypanosomatid parasites. FMICB 3: 1-10.

Braga FG, Bouzada ML, Fabri RL, Matos MO, Scio E AND COIMBRA ES. 2007. Antileishmanial and antifungal activity of plants used in traditional medicine in Brazil. J Ethnopharmacol 111: 396-402. 
Brenzan MA, NaKamura CV, Prado Dias Filho B, UedaNAKAMURA T, YOUNG MC AND APARÍCIO GARCIA CORTEZ D. 2007. Antileishmanial activity of crude extract and coumarin from Calophyllum brasiliense leaves against Leishmania amazonensis. Parasitol Res 101: 715-722.

Brito AMG, Dos SANTOS D, Rodrigues SA, Brito RG AND XAVIER-FILHO L. 2013. Plants with anti-Leishmania activity: Integrative review from 2000 to 2011. Pharmacog Rev 7: 34-41.

CAIXETA SC ET AL. 2011. Chemical composition and in vitro schistosomicidal activity of the essential oil of Plectranthus neochilus grown in southeast Brazil. Chem Biodivers 8: 2149-2157.

Chiappeta ADA, De Mello JF AND Maciel GM. 1983. Higher plants with biological activity- Plants of Pernambuco. Rev Inst Antibiot 21: 43-50.

CorrêA MP And Penna LA. 1984. Dicionário de Plantas Úteis do Brasil e das Exóticas Cultivadas. Rio de Janeiro: Ministério da Agricultura, $747 \mathrm{p}$.

CROFT SLAND OLLIARO P. 2011. Leishmaniasis chemotherapychallenges and opportunities. Clin Microbiol Infec 17: 1478-1483.

Cruz AK, De Toledo JS, Falade M, Terrão $M$, KAMCHONWONGPAISAN S AND UTHAIPIBULL C. 2009. Current treatment and drug discovery against Leishmania spp. and Plasmodium spp.: a review. Curr Drug Targets 10: 178-192.

Da Silva SL, CALgarotto AK, CHAar JS AND MARANGONI S. 2008. Isolation and characterization of ellagic acid derivatives isolated from Casearia sylvestris Sw. aqueous extract with anti-PLA2 activity. Toxicon 52: 655-666.

De Morais-Teixeira E, Damasceno QS, Galuppo MK, ROMANHA AJ AND RABEllo A. 2011. The in vitro leishmanicidal activity of hexadecylphosphocholine (miltefosine) against four medically relevant Leishmania species of Brazil. Mem Inst Oswaldo Cruz 106: 475-478.

De Muylder G, Ang KK, Chen S, Arkin MR, Engel JC AND MCKERROW JH. 2011. A screen against Leishmania intracellular amastigotes: comparison to a promastigote screen and identification of a host cell-specific hit. PLos Negl Trop Dis 5: e-1253.

Dorlo TPC, Balasegaram M, BeiJnen J AND De VRIES PJ. 2012. Miltefosine: a review of its pharmacology and therapeutic efficacy in the treatment of leishmaniasis. J Antimicrob Chemother 67: 2576-2597.

Dustan CA, Noreen Y, Serrano G, Cox PA, Perera P AND Bohlin L. 1997. Evaluation of some Samoan and Peruvian medicinal plants by prostaglandin biosynthesis and rat ear oedema assays. J Ethnopharmacol 57: 35-56.

Fabri RL, CoImbra ES, Almeida AC, Siqueira EP, Alves TM, ZANI CL AND SCIO E. 2012a. Essential oil of Mitracarpus frigidus as a potent source of bioactive compounds. An Acad Bras Cienc 84: 1073-1080.
FABRI RL, GRAZUL RM, CARVALHO LO, COIMBRA ES, CARDOSO GM, SOUZA-FAGUNDES EM, SILVA AD AND ScIO E. 2012b. Antitumor, antibiotic and antileishmanial properties of the Pyranonaphthoquinone Psychorubrin from Mitracarpus frigidus. An Acad Bras Cienc 84: 1081-1090.

Ferreira PMP, Costa-Lotufo LV, Moraes MO, Barros FWA, MARTINS AMA, CAVALHEIRO AJ, BOLZANI VS, Santos AG And Pessoa C. 2011. Folk uses and pharmacological properties of Casearia sylvestris: a medicinal review. An Acad Bras Cienc 83: 1373-1384.

Ferreira PMP, SANtos AG, Tininis AG, Costa PM, CaValheiro AJ, Bolzanivs Moraes MO, CostaLotufo LV, Montenegro RC And Pessoa C. 2010. Casearin X exhibits cytotoxic effects in leukemia cells triggered by apoptosis. Chem Biol Interact 188: 497-504.

HAJDU Z AND HoHMANN J. 2012. An ethnopharmacological survey of the traditional medicine utilized in the community of Porvenir, Bajo Paraguá Indian Reservation, Bolivia. J. Ethnopharmacol 139: 838-857.

Lima ZP, Bonamin F, Calvo TR, Vilegas W, Santos LC, Rozza AL, PEllizzon CH, Rocha LRM AND HiRumaLIMA CA. 2011. Effects of the ethyl acetate fraction of Alchornea Triplinervia on healing gastric ulcer in rats. Pharmaceut 4: 1423-1433.

LoRENZI H AND MATOS FJA. 2002. Plantas Medicinais no Brasil: Nativas e Exóticas Cultivadas. São Paulo: Plantarum, 544 p.

Menezes PR, Schwarz EA AND SANTOS CAM. 2004. In vitro antioxidant activity of species collected in Paraná. Fitoterapia 75: 398-400.

Mesquita ML, Desrivot J, Bories C, Fournet A, Paula Je, GRELLIER P, AND ESPÍNDOLA LS. 2005. Antileishmanial and trypanocidal activity of Brazilian Cerrado plants. Mem Inst Oswaldo Cruz 100: 783-787.

MinOdier P AND PAROLA P. 2007. Cutaneous leishmaniasis treatment. Travel Med Infect Dis 5: 150-158.

Moreira DL AND GuARIM-Neto G. 2009. Usos Múltiplos de Plantas do Cerrado: Um Estudo Etnobotânico na Comunidade Sítio Pindura, Rosário Oeste, Mato Grosso, Brasil. Polibotânica 27: 159-190.

Mossman T. 1983. Rapid colorimetric assay for cellular growth and survival: application to proliferation and cytotoxicity assays. J Immunol Methods 65: 55-58.

Murray HW, BERMAN JD, DaVIES CR AND SARAVIA NG. 2005. Advances in leishmaniasis. Lancet 366: 1561-1577.

SAntin MR, Dos Santos AO, Nakamura CV, Dias Filho BP, FERREIRA ICP AND NAKAMURA TU. 2009. In vitro activity of the essential oil of Cymbopogon citratus and its major component (citral) on Leishmania amazonensis. Parasitol Res 105: 1489-1496.

SANTOS DO ET AL. 2008. Leishmaniasis treatment - a challenge that remains: a review. Parasitol Res 103: 1-10.

Scio E, Mendes RF, Motta EVS, Bellozi PMQ, Aragão DMO, MELlo J, FABRI RL, MOREIRA JR, ASSIS IVL AND BouZADA MLM. 2012. Antimicrobial and Antioxidant Activities of Some Plant Extracts. In: RAO V (Ed), Phytochemicals as Nutraceuticals - Global Approaches to Their Role in Nutrition and Health: InTech, 278 p. 
SILVA ALN, ADADE CM, SHOYAMA FM, NETO CPS, PADRÓN TS, ALMEIDA MV, REZENDE CAM, SILVA CV AND SOUZA MA. 2012. In vitro leishmanicidal activity of N-dodecyl1,2-ethanediamine. Biomed Pharmacother 66: 180-186.

SINGH B AND SUNDAR S. 2012. Leishmaniasis: vaccine candidates and perspectives. Vaccine 30: 3834-3842.

SUNDAR S, JHA TK, THAKUR CP, BHATTACHARVA SK AND RAI M. 2002. Oral miltefosine for Indian visceral leishmaniasis. N Engl J Med 347: 1739-1746.
Tempone AG, De Oliveira CM AND Berlinck RS. 2011. Current Aproaches to Discover Marine Antileishmanial Natural Products. Planta Med 77: 572-585.

WHO. 2010. Control of the leishmaniasis: report of a meeting of the WHO Expert Committee on the Control of leishmaniases. In: WHO Technical Report Series. Geneva, p. 22-26.

WHO. 2013. Leishmaniasis. http://www.who.int/leishmaniasis/en/, accessed Nov 2013. 